\title{
Interleukin-10 in Human Milk
}

\author{
ROBERTO GAROFALO, SADHANA CHHEDA, FANG MEI, KIMBERLY H. PALKOWETZ, HELEN \\ E. RUDLOFF, FRANK C. SCHMALSTIEG, DAVID K. RASSIN, AND ARMOND S. GOLDMAN
}

The University of Texas Medical Branch, The Department of Pediatrics, Galveston, Texas 77555-0369

\begin{abstract}
The concentrations of immunoreactive IL-10 in the aqueous fraction of 20 specimens of human milk obtained during the first $80 \mathrm{~h}$ of lactation and stored at $-60^{\circ} \mathrm{C}$ ranged from 66 to 9301 $\mathrm{pg} / \mathrm{mL}$ (mean $\pm \mathrm{SD}, 3304 \pm 3127 \mathrm{pg} / \mathrm{mL}$ ). IL-10 was present also in the lipid layer of milk. Gel filtration revealed that $\mathrm{IL}-10$ was located in a high molecular weight fraction, where certain other cytokines in human milk have been found. In addition, immunoreactive IL-10 in milk increased after treatment with sodium taurocholate. Bioactive IL-10 was demonstrated by the finding that human milk inhibited $\left[{ }^{3} \mathrm{H}\right]$ thymidine uptake by human blood lymphocytes and that inhibition was partly overcome by concomitant incubation with antibodies to human IL- 10 . IL-10 mRNA but no protein product was found in cultured
\end{abstract}

There is recent evidence that the immune system in human milk is composed not only of direct-acting antimicrobial agents and antiinflammatory factors, but also of immunoregulators (1). The immunoregulators in early human milk secretions include the proinflammatory cytokines TNF- $\alpha$ (concentrations, $\sim 620 \pm 183 \mathrm{pg} / \mathrm{mL}$ ) (2), IL-1 $\beta$ (concentrations, $\sim 1130 \pm 478$ $\mathrm{pg} / \mathrm{mL}$ ) (3), IL-6 (concentrations, $\sim 151 \pm 89 \mathrm{pg} / \mathrm{mL}$ ) $(4,5)$, and IL-8 (concentrations, $\sim 3684 \pm 2910 \mathrm{pg} / \mathrm{mL}$ ) (6). The patterns of the concentrations of these cytokines in human milk suggested that the the levels were physiologically significant. It was ascertained that the production of TNF- $\alpha$ by human milk leukocytes could not be augmented by the addition of $N$-formylL-methionyl-L-leucyl-1-phenylalanine or $4 \beta$-phorbol- $12 \beta$-myristate$13 \alpha$-acetate to those cells in culture (2). Thus, the low production of IL-1 (7) and TNF- $\alpha$ (2) by leukocytes in human milk further suggested that human milk contains factors that regulate synthesis of proinflammatory cytokines.

Because of the above evidence and the antiinflammatory character of the protection afforded by human milk, we hypothesized that human milk contains antiinflammatory cytokines. One antiinflammatory cytokine, TGF- $\beta 2$, had already been found in human milk $(6,8$,

Received May 11, 1994; accepted December 12, 1994

Correspondence: Armond S. Goldman, M.D., Professor and Director, Division of Immunology/Allergy, Department of Pediatrics, Room C2-37A, Children's Hospital, The University of Texas Medical Branch, 301 University Boulevard, Galveston, TX 775550369 .

Supported by Wyeth-Ayerst Nutritional Research and a grant from the Child Health and Human Development Branch of the National Institutes of Health (R30 HD 27841). human mammary epithelial cells. Some IL-10 was associated with preparations of human milk leukocytes, but the data did not suggest that the cells were producing the cytokine. Bioactive IL-10 in a possible protected compartment suggests that IL-10 in human milk may have immunomodulating, antiinflammatory effects on the alimentary tract of the recipient infant. (Pediatr Res 37: 444-449, 1995)

\section{Abbreviations}

TNF- $\alpha$, tumor necrosis factor- $\alpha$

TGF- $\boldsymbol{\beta} 2$, transforming growth factor- $\beta 2$

PCR, polymerase chain reaction
9 ), but it seemed likely that others would be present. The most likely candidate was IL-10 for the following reasons. IL-10, an $18-\mathrm{kD}$ protein homodimer that is a member of the $\alpha$-helix family of hematopoietic cytokines (10), has an array of antiinflammatory properties $(11,12)$. These include the ability to inhibit the production of IL-1, IL-2, IL-6, IL-8, TNF- $\alpha$, granulocyte-macrophage colony-stimulating factor, granulocyte colony-stimulating factor, macrophage migration inhibitory factor, and interferon- $\gamma(13-20)$, many of which are proinflammatory cytokines. Therefore, we undertook an investigation to determine whether IL-10 was present in human milk in sufficient quantities to regulate the production of proinflammatory cytokines and to display other immunoregulatory properties attributed to this agent. This study became possible because of the recent availability of reagents to quantify human IL-10.

\section{METHODS}

Subject selection-human research assurances. The use of human subjects was approved by the Institutional Review Board for Human Research of The University of Texas Medical Branch at Galveston. Informed consent was obtained from each participant in the investigation. The 20 subjects recruited for this study were healthy adult women who delivered normal newborns after full-term pregnancies.

Specimen collections. One milk specimen was obtained from each of the 20 subjects during the first $80 \mathrm{~h}$ of lactation (mean postpartum time, $39 \mathrm{~h}$; range, 12-80 h). Human milk was collected into sterile polypropylene containers by a low- 
pressure electric pump (Egnell, Inc., Irvine, IL). Each specimen was centrifuged at $680 \times \mathrm{g}$ for $10 \mathrm{~min}$ to obtain an aqueous fraction, a lipid layer, and a cell preparation, the latter of which had the majority of lipids, milk fat globules, membranes, and micelles removed. The aqueous fraction of milk was examined immediately or was stored at $-60^{\circ} \mathrm{C}$ for a few days until analyses were performed.

Immunoquantitation of $\boldsymbol{I L}-\mathbf{1 0}$. IL-10 in the human milk preparations was quantified by a sandwich ELISA method that used capture rat MAb (IgG1 isotype; clone, JES3-9D7) to human recombinant IL-10 and detector biotinylated rat MAb (IgG2a isotype; clone, JES3-12G8) to human recombinant IL-10 (3 $\mu \mathrm{g} / \mathrm{mL}$ of each antibody preparation; Pharmigen, San Diego, CA). The reactions were developed with streptavidinhorseradish peroxidase (Sigma Chemical Co., St. Louis, MO) and carried out in microtiter plates (Immunol-2 plates; Dynatech, Chantilly, VA). The reaction product was detected with $O$-phenylenediamine dihydrochloride (Sigma Chemical Co.). Half-maximal optical absorbance $(492-540 \mathrm{~nm})$ readings were used as end points. Standard plots for converting the optical absorbance readings to concentrations of IL-10 were constructed by measuring known concentrations of human recombinant IL-10 (R \& D Systems, Inc., Minneapolis, MN). This was accomplished by plotting the log of the standard concentrations of recombinant human IL-10 (pg/mL) against the log of the optical absorbance readings.

The sensitivity of the measurement was $80 \mathrm{pg} / \mathrm{mL}$. Values between 80 and $1200 \mathrm{pg} / \mathrm{mL}$ of the protein were detected by the assay. The coefficient of variation of the measurements was $\sim 1-2 \%$. The validity of the assay for quantifying IL-10 in human milk was tested by the following experiment. A human milk preparation was divided into two aliquots. Two hundred picograms of human recombinant IL-10 (R \& D Systems, Inc.) were added to one aliquot. IL-10 was then quantified by the previously described ELISA. In addition to the endogenous IL-10 in the preparation, over $98 \%$ of the exogenous IL-10 was detected.

To further validate the method for quantifying IL-10 in human milk, experiments were carried out to determine the effects of two different storage temperatures upon the detection of IL-10 in human milk. In those experiments, milk samples were divided into two aliquots. The first was maintained at $-60^{\circ} \mathrm{C}$ for $10 \mathrm{~d}$. The second was stored $-60^{\circ} \mathrm{C}$ for $72 \mathrm{~h}$ and then was thawed and maintained at $4^{\circ} \mathrm{C}$ for an additional $72 \mathrm{~h}$. The second preparation was split into two fractions, one that was maintained at $4^{\circ} \mathrm{C}$ and the other that was stored at $-60^{\circ} \mathrm{C}$ for $3 \mathrm{~d}$ more.

Physical distribution of IL-10 in human milk. Because of reports that TNF- $\alpha$ and some IL- 6 in human milk are present in a high molecular weight fraction of human milk $(2,4)$, the physical distribution of IL-10 in human milk was examined in two ways. The first approach was to examine whether IL-10 was present in the lipid layer that was obtained by centrifuging fresh whole milk at $680 \times g$ for $10 \mathrm{~min}$. The second approach was to determine whether treatment of human milk with an artificial detergent, polyoxyethylene sorbitan monolaurate (Tween 20; Sigma Chemical Co.), and a bile salt, sodium taurocholate, leads to the release of additional immunoreactive human IL-10. That was accomplished by adding polyoxycthylene sorbitan monolaurate $(0.025 \%)$ to whole fresh milk or sodium taurocholate $(12 \mathrm{mM})$ to either the aqueous or lipid fraction of three specimens of human milk and incubating the mixture for $30 \mathrm{~min}$ at room temperature. Controls for this experiment were aliquots of untreated whole milk or untreated fractions of the milk obtained by centrifugation.

The third approach was fractionation of milk by column chromatography. Defatted, acellular human milk was applied to a Sephacryl S-200 gel filtration column (Pharmacia Biotechnol Inc., Piscataway, NJ). The molecular mass standards were blue dextran (250 kD), BSA (68 kD), carbonic anhydrase (29 $\mathrm{kD})$, and cytochrome $c(12.4 \mathrm{kD})$. Each eluted fraction was assayed for IL-10 by the previously described ELISA.

Bioactivity of $I L-10$ in human milk. The bioactivity of IL-10 in human milk was examined by determining whether human milk inhibited the uptake of $\left[{ }^{3} \mathrm{H}\right]$ thymidine by human peripheral blood mononuclear leukocytes $(>90 \% \mathrm{~T}$ cells by immunofluorescent flow cytometry) that were unstimulated or stimulated with antibodies to human CD3 (OKT3, $0.025 \mu \mathrm{g}$ ) $\mathrm{mL}$ ), and whether that inhibition could be partially blocked by the addition of specific murine MAb to human recombinant IL-10 (19F1) (1:2000 dilution) (hybridoma from the American Type Culture Collection) (15). Human recombinant IL-10 (2 $\mathrm{ng} / \mathrm{mL}$ ) was used as a positive control in the experiments. About $2 \times 10^{5}$ mononuclear leukocytes were used in each microtiter well. In those preparations stimulated with antibodies to CD3, the wells were precoated overnight with antibodies before blood mononuclear leukocytes were added. The cells were cultured for $72 \mathrm{~h}$ at $37^{\circ} \mathrm{C}$ in $7 \% \mathrm{CO}_{2}$. Four hours before harvest, the cells were pulsed with $1.0 \mu \mathrm{Ci}$ of $\left[{ }^{3} \mathrm{H}\right]$ thymidine. The uptake of $\left[{ }^{3} \mathrm{H}\right]$ thymidine by the cells was then quantified by scintillation spectroscopy.

Source of IL-10 in human milk. Two potential sources of IL-10 in human milk were tested. The first were cell preparations ( $>95 \%$ leukocytes) obtained from milk specimens by centrifuging the specimens at $680 \times g$ for 10 min and washing them three times in Hanks' balanced salt solution. These preparations contained not only cells but also high-density milk fat globules and other particulate material. Cell viability as determined by trypan blue exclusion was $\sim 95 \%$. The number of cells in the preparations ranged between 9 and $20 \times 10^{6} / \mathrm{mL}$. Aliquots of unfractionated cells were sonicated or incubated in RPMI 1640 for 4 or $24 \mathrm{~h}$ in $7 \% \mathrm{CO}_{2}$ at $37^{\circ} \mathrm{C}$. The sonicated cells were centrifuged at $1000 \times \mathrm{g}$ for $3-5 \mathrm{~min}$ to remove particulate materials; supernatants from the incubated cells were separated by centrifugation at $680 \times g$ for 3-5 min. Supernatants from sonicated cells and the supernatants from the cultured milk leukocytes were then assayed for IL-10 by the previously described ELISA.

A spontaneously immortalized human mammary gland cell line (MCF-10) derived from an adult woman with fibrocystic disease of the breast (American Type Culture Collection) (21, 22) was examined for the presence of IL-10 mRNA and for its ability to produce the cytokine. The cells are SV40-free, not tumorigenic in nude mice, and positive for sialomucins, keratins, and surface protein antigens found on normal human mammary gland epithelial cells. In contrast, they have no 
features of myoepithelial or stromal cells $(21,22)$. The reported diploid pattern with a balanced chromosome 1-3-9 translocation $(21,22)$ was confirmed in the Cytogenetics Laboratory of this institution. These nonneoplastic cells have also been found to produce IL-6 and IL-8 (6).

The mammary epithelial cells were cultured on 24-well plastic plates (Costar Delta Packaging Corporation, Cambridge, MA) in the presence of insulin (Sigma Chemical Co.) (10 mg/mL), hydrocortisone (Sigma Chemical Co.) (500 ng/ $\mathrm{mL}$ ), and epithelial growth factor (Sigma Chemical Co.) (20 $\mathrm{ng} / \mathrm{mL}$ ) with or without an extracellular matrix (a mixture of enactin, collagen IV, and laminin; E-C-L Cell Attachment Matrix, lot no. 11645, Upstate Biotechnology Inc., Lake Placid, NY) until they reached confluency. Adherent cells were washed gently and fresh culture media was added. The number of cells in each well was not determined, because the experiments were not designed to examine the quantitative relationships between the number of cells and the amount of IL-10 that was produced, but the number of cells, as estimated from other experimental observations in our laboratory, was between 3-5 $\times 10^{5}$ cells/well. After $24 \mathrm{~h}$ of additional culture at $37^{\circ} \mathrm{C}$ in $7 \%$ $\mathrm{CO}_{2}$, supernatant fluids and sonicated cells were harvested and IL-10 quantified by the previously described ELISA.

Cultured mammary gland epithelial cells were also examined for the expression of the mRNA for human IL-10 by the following reverse-transcriptase PCR and Southern blot methods. Total RNA was isolated from $5 \times 10^{6} \mathrm{MCF}-10$ cells by the acid-guanidinium method (23). One microgram of total RNA was reverse transcribed using random hexamers as the primer. Twenty microliters of each sample were then subjected to PCR using IL-10 primers (see below) in $100-\mu \mathrm{L}$ volumes with PCR buffer $\left(\mathrm{MgCl}_{2}, 2 \mathrm{mM} ; \mathrm{KCl}, 50 \mathrm{mM}\right.$; and Tris- $\mathrm{HCl}$, $10 \mathrm{mM}$ ), and Taq DNA polymerase in a thermal cycler (Perkin-Elmer, Norwalk, CT). Samples were denatured at $90^{\circ} \mathrm{C}$ for $45 \mathrm{~s}$, annealed at $60^{\circ} \mathrm{C}$ for $45 \mathrm{~s}$, and extended at $70^{\circ} \mathrm{C}$ for 120 $\mathrm{s}$, for 30 cycles. PCR products were then size-fractionated on $8 \%$ acrylamide gels. Subsequently, gels were denatured for $1 \mathrm{~h}$ at room temperature in $0.5 \mathrm{M} \mathrm{NaOH}$ and $1.5 \mathrm{M} \mathrm{NaCl}$ and transferred to nylon membranes. Membranes were prehybridized in $5 \times$ SSPE, $0.01 \%$ SDS, $1 \times$ Denhardt's solution and $200 \mu \mathrm{g} / \mathrm{mL}$ of salmon sperm DNA (Sigma Chemical Co.) for $2 \mathrm{~h}$ at $40^{\circ} \mathrm{C}$.

Membranes were subsequently hybridized with a ${ }^{32} \mathrm{P}-3^{\prime}$ end-labeled complementary oligonucleotide probe, specific for a sequence internal to the primers used in the amplification (see below). As a positive control, a human IL-10 cDNA fragmentation (Clontech, Palo Alto, CA) was included. After hybridization for $14 \mathrm{~h}$ at $40^{\circ} \mathrm{C}$, filters were washed in $5 \times$ SSPE and $0.01 \%$ SDS and exposed to Kodak XAR-5 films for $24 \mathrm{~h}$. Primers and probe used were as follows: IL-10 sense primer $5^{\prime}$ - A A G CTGA GAA C CAAGA CCCA GA GA CA T CAAGGCG, IL-10 antisense primer AGCTATCCCAGAGCCCCAGATCCGATTTTGG, IL-10 oligo-probe AGCAGGTGAAGAATGCCTTT, $\beta$-actin sense primer $5^{\prime}$-GTGGGGCGCCCCAGGCACCA, $\beta$-actin antisense primer GTCCTTAATGTCACGCACGATTTC (Clontech).

Statistical methods. Group data were presented as means \pm SD. Differences in the concentrations of IL-10 in milk speci- mens collected during the first $24 \mathrm{~h}$ and thereafter were tested by a nonparametric method based on ranks (24).

\section{RESULTS}

Concentrations of IL-10 in human milk. The concentrations of IL-10 in 20 specimens of human milk (one measurement from each subject) collected during the first $80 \mathrm{~h}$ of lactation were $3304 \pm 3127 \mathrm{pg} / \mathrm{mL}$ (Fig. 1). As shown by a rank order nonparametric analysis, IL-10 concentrations were higher during the first $24 \mathrm{~h}$ postpartum $(p<0.05)$.

Effect of storage temperatures on quantitation of $I L-10$ in human milk. In paired experiments, concentrations of IL-10 in milk stored at $-60^{\circ} \mathrm{C}$, thawed, and then stored at $4^{\circ} \mathrm{C}$ for $72 \mathrm{~h}$ increased by $2 \%$ in one specimen and fell by 8,27 , and $30 \%$, respectively, from three specimens stored at $-60^{\circ} \mathrm{C}$ for $10 \mathrm{~d}$. When aliquots kept at $4^{\circ} \mathrm{C}$ for $72 \mathrm{~h}$ were placed at $-60^{\circ} \mathrm{C}$ for $72 \mathrm{~h}$, detectable levels of IL-10 increased to values found in the original frozen preparations.

Physical distribution of IL-10 in human milk. IL-10 was detected in the lipid layer of two specimens of fresh human milk that were tested (116 and $1155 \mathrm{pg} / \mathrm{mL}$, respectively). After treatment of one specimen of whole milk with polyoxyethylene sorbitan monolaurate, the concentration of immunologically detectable IL-10 rose from 930 to $2553 \mathrm{pg} / \mathrm{mL}$. No further studies with that artificial detergent were pursued, because we were more interested in examining the effects of one of the bile salt that occurs in small intestine, sodium taurocholate. Sodium taurocholate caused an increase in the amount of immunoreactive IL-10 from both the aqueous and the lipid phase of human milk of the three specimens that were tested. In the first specimen, the amount in the aqueous phase rose from $236 \mathrm{pg}$ to $441 \mathrm{pg} / \mathrm{mL}$ and the amount in the lipid layer increased from 161 to $312 \mathrm{pg} / \mathrm{mL}$. Only the aqueous phase was examined in the second specimen. No IL-10 was detected before treatment; $250 \mathrm{pg} / \mathrm{mL}$ was found after treat-

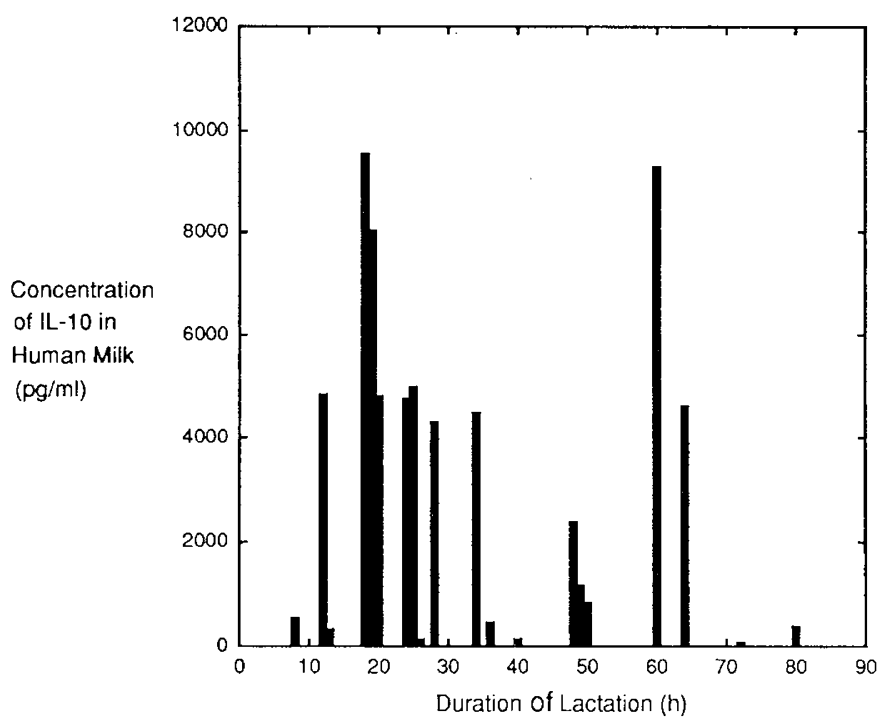

Figure 1. Concentrations of IL-10 in the aqueous phase of 20 specimens of human milk determined by a sandwich ELISA. The concentrations of IL-10 wcre highest in the first $24 \mathrm{~h}$ of lactation (i.e. postpartum period) $(p<0.05)$. 
ment. In the third specimen, the lipid layer was tested; the concentration of immunologically detectable IL-10 rose from 1155 to $2618 \mathrm{pg} / \mathrm{mL}$.

Further evidence for possible compartmentalization of IL-10 in human milk was found in the gel filtration experiments. In those studies, IL-10 was detected principally in a high molecular mass fraction $(\sim 80 \mathrm{kD})$ of human milk (Fig. 2).

Bioactivity of IL-10 in human milk. In three experiments, the inhibition of $\left[{ }^{3} \mathrm{H}\right]$ thymidine incorporation by human blood $\mathrm{T}$ cells exposed to human milk was similar to that found with $\mathrm{T}$ cells treated with human recombinant IL-10 (see Fig. 3 for representative data). Human milk inhibited the uptake of $\left[{ }^{3} \mathrm{H}\right]$ thymidine by human peripheral blood mononuclear leukocytes that were or were not stimulated with antibodies to CD3, and that the inhibition in both situations was partially blocked by the addition of neutralizing antibodies to human IL-10 (Fig. $3)$.

Source of IL-10 in human milk. Although low levels of IL-10 were associated with the human milk leukocyte preparations (data not shown), the data do not suggest that IL-10 is produced by those cells. That is consistent with the reported inability to detect IL-10 in human milk leukocytes by immunofluorescence (25).

Constitutive expression of mRNA for IL-10 by the spontaneously immortalized human mammary gland cell line was demonstrated by Southern blotting (Fig. 4). The DNA product obtained from PCR reactions using primers for IL-10 hybridized with a probe specific for human IL-10, and the size of the PCR product was 328 bp (Fig. 4). However, only small amounts of IL-10 were detected in human mammary gland epithelial cells cultured on plastic (intracellular concentrations, $24 \pm 7 \mathrm{pg} / \mathrm{mL}$ of sonicated cells; extracellular concentrations, $20 \pm 1 \mathrm{pg} / \mathrm{mL}$ of supernatant) or from cells cultured on an extracellular matrix (data similar to that shown above, but not included).

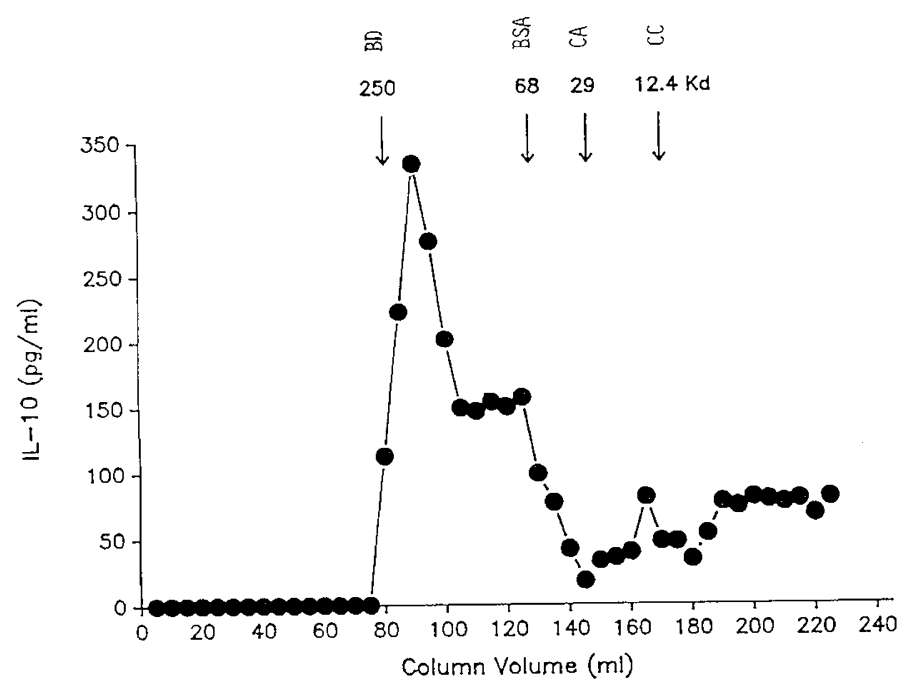

Figure 2. Gel filtration of human milk on a Sephacryl S-200 column. Defatted, acellular milk was applied to the column. Proteins were eluted from the column with a standard borate buffer. Molecular mass markers were bluc dextran $(B D, 250 \mathrm{kD})$, BSA $(68 \mathrm{kD})$, carbonic anhydrase $(C A, 29 \mathrm{kD})$, cytochrome $c(C C, 12.4 \mathrm{kD})$. IL-10 was detected in a molecular mass fraction $>80 \mathrm{kD}$.
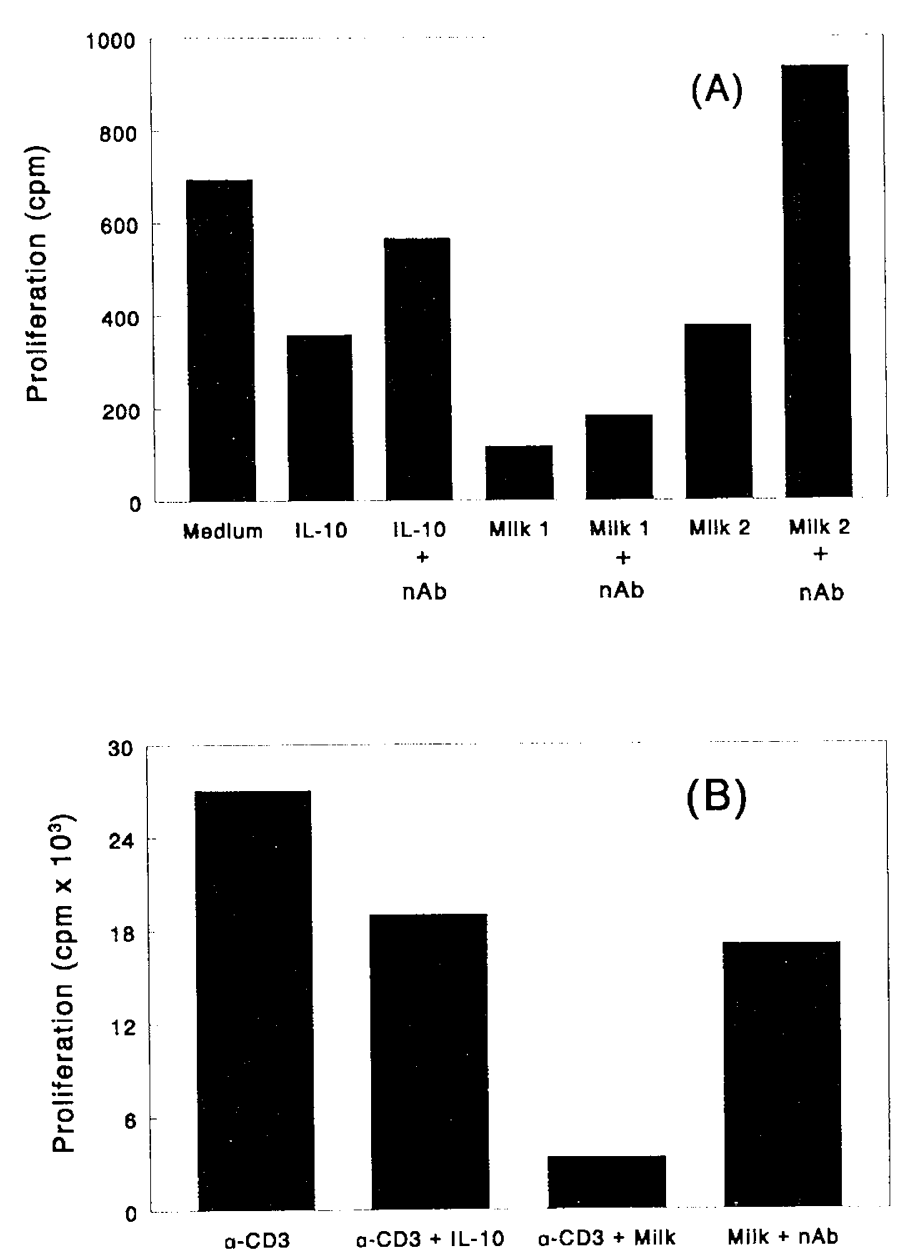

Figure 3. Bioactivity of IL-10 in human milk. The bioactivity of IL-10 in human milk was examined by determining whether human milk inhibited the uptake of $\left[{ }^{3} \mathrm{H}\right]$ thymidine by human pcripheral blood mononuclear leukocytes, and whether that inhibition was partially blocked by the addition of neutralizing antibodies $(n A b)$ against recombinant human IL-10. Representative data from cells cultured in the absence $(A)$ or presence $(B)$ of antibodies to CD3 $(\alpha-C D 3)$ arc shown. The uptake of $\left[{ }^{3} \mathrm{H}\right]$ thymidine (proliferation) is expressed on the $y$ axis as cpm.

\section{DISCUSSION}

In this study, physiologically significant concentrations of immunoreactive IL-10 were found in the aqueous phase of early human milk secretions. Indeed, the concentrations of IL-10 in the aqueous phase of human milk were greatcr than other immunochemically measured cytokines in milk, except for IL-8 (6). IL-10 concentrations were highest at 12-24 h of lactation. If $\sim 120 \mathrm{~mL}$ of milk are produced during the first few days postpartum (26), then $\sim 350 \mathrm{ng}$ of IL-10 would be secreted per day.

To further interpret the quantitative measurements, the physical state of IL-10 in human milk was investigated. Evidence was found that some IL-10 was present in a nonaqueous phase as well as the aqueous phase of human milk. IL-10 was demonstrated in the lipid fraction of human milk, incrcased amounts of IL-10 were detected after the aqueous or lipid phase of human milk was treated with sodium taurocholate, and IL-10 was detected in a high molecular mass column chromatography fraction $(>80 \mathrm{kD})$ where human recombinant 


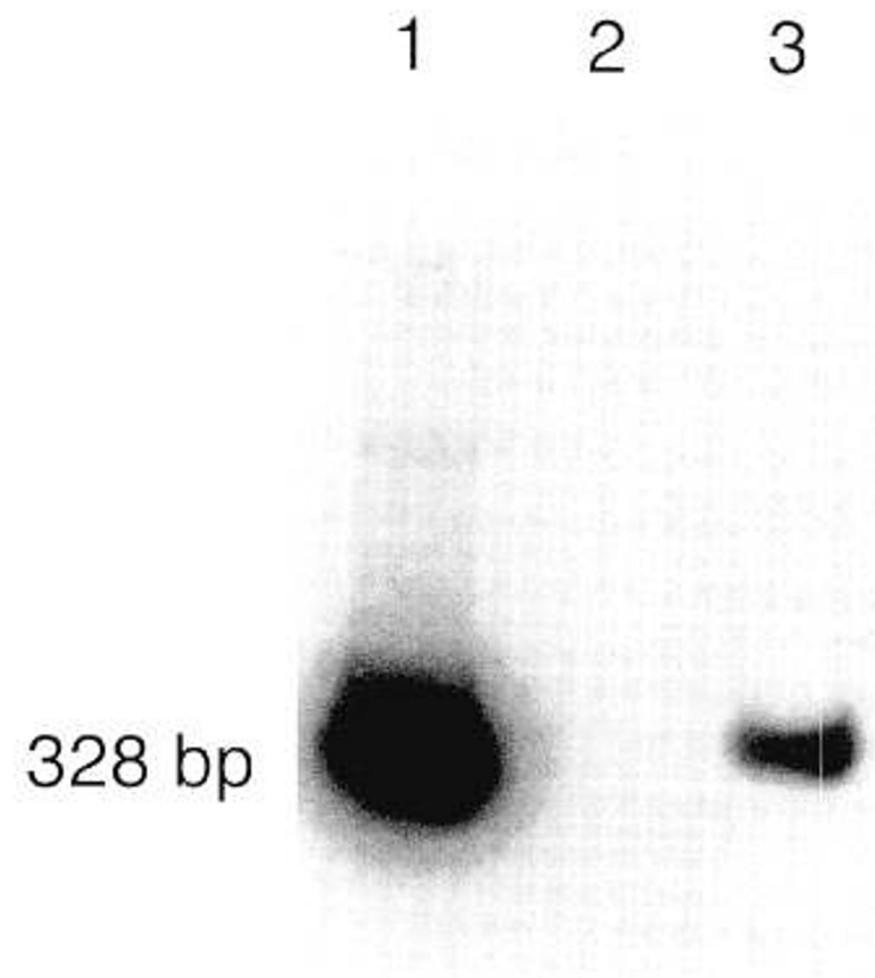

Figure 4. Demonstration by Southern blotting of constitutive expression of mRNA for IL- 10 by spontaneously immortalized human mammary gland cells. Lane $I$ is a positive control IL-10 cDNA fragment, lane 2 is a negative control (watcr), and lane 3 is the PCR product from mammary epithelial cells. The sizes of the PCR product from the positive control and the mammary gland epithelial cells were identical ( $328 \mathrm{bp}$ ).

IL-10 would not be anticipated, but where TNF- $\alpha$ and a significant proportion of IL- 6 in human milk reside $(2,4)$. Therefore IL-10 in human milk may be bound to other proteins or compartmentalized in human milk. One possibility is that IL-10 in human milk is a complex of a dimer of the cytokine $(37 \mathrm{kD})$ bound to its receptor $(60 \mathrm{kD})(27)$. Regardless of its precise physical state, the experiments suggest that the total IL-10 in human milk is significantly higher than the amounts measured in the aqueous phase of milk, and that some of it may be released after encountering physiologic concentrations of bile salts (28) such as were used in these experiments.

Does that finding suggest that IL-10 in human milk is secreted in an apocrine fashion from mammary epithelial cells? There is in vitro evidence of IL-6 and IL- 8 production and secretion by human mammary gland epithelial cells $(6,29)$. The in vitro experimental conditions with those cells do not completely model the in vivo environment of mammary gland epithelium. Only small amounts of IL-10 protein were detected in those cell preparations, but the mRNA for the cytokine was constitutively expressed by them. It therefore seems possible that IL-10 is produced in vivo by mammary gland epithelial cells. Although no evidence of IL-10 production by the leukocytes in human milk was found, we cannot rule out the possibility that some IL-10 was produced by those cells while they were in the mammary gland.
The sequence of production of cytokines in human milk and the interplay between them is unknown. Inasmuch as IL-10 inhibits the production of IL-1, IL-6, IL-8, and TNF- $\alpha$ (30) and TNF- $\alpha$ stimulates the production of IL-10 (31), IL-10 may be produced sometime after the synthesis of the proinflammatory cytokines. Experimental animal models may be required to examine that question.

This investigation demonstrates that IL-10 in human milk is bioactive. Indeed, those results are in keeping with a previous report that human milk inhibits the production of IL-2 by stimulated human blood $\mathrm{T}$ cells (32). In addition, recent experiments in our laboratory suggest that human newborns have a developmental delay in the production of IL-10 by blood leukocytes (unpublished data). Thus, bioactive IL-10 in human milk may be necessary during that period of developmental delay.

How would IL-10 in human milk affect the recipient infant? Several possibilities are suggested from past in vitro investigations of the biologic activities of IL-10. IL-10 inhibits the formation of proinflammatory cytokines by monocytes/ macrophages (11-15), limits the participation of Th1 cells in delayed hypersensitivity (33-35), attracts $\mathrm{CD} 8^{+} \mathrm{T}$ cells (36), and enhances the growth and differentiation of and immunoglobulin synthesis by B cells (37-41), including acting as a cofactor with $\mathrm{TGF}-\beta$ to increase $\operatorname{IgA} 1$ and $\operatorname{IgA} 2$ production (40). Thus, IL-10 in human milk may aid in regulating mucosal defenses and limiting inflammatory reactions in the upper parts of the alimentary and respiratory tracts.

Is ingested IL-10 active past the esophagus? In that regard, there are high concentrations of antiproteases in human milk (42) and low concentrations of $\mathrm{H}^{+}$in gastric secretions, a lack of intragastric protein digestion, and poor production of trypsin and chymotrypsin during the first week of life (43). In addition, part of the IL-10 in human milk may be protected by compartmentalization from gastrointestinal digestion.

Our in vitro experiments also suggest that compartmentalized IL-10 is released after exposure to bile salts in the duodenum. Consequently, it is likely that the released IL-10 would aid in protecting the intestinal tract. Indeed, the occurrence of a severe enterocolitis in IL-10-deficient mice generated by gene targeting (44) suggests that IL-10 plays an important role in regulating the defenses of the intestinal tract against inflammatory processes associated with enteric infections.

In summary, IL-10 may bridge the immunomodulating and antiinflammatory segments of the defense system in human milk. Both short- and long-term effects of cytokines in human milk upon the mother, and the recipient infant will require further exploration.

Acknowledgment. The authors thank Susan C. Kovacevich for her secretarial assistance in the preparation of the manuscript.

\section{REFERENCES}

1. Goldman AS 1993 The immune system of human milk. Antimicrobial, antiinflammatory, and immunomodulating propertics. Pediatr Infect Dis J 12:664-672 
2. Rudloff HE, Schmalstieg FC, Mushtaha AA, Palkowetz KH, Liu SK, and Goldman AS 1992 Tumor necrosis factor- $\alpha$ in human milk. Pediatr Res 31:29-33

3. Munoz C, Endres S, van der Meer J, Schlesinger L, Arevalo M, Dinarello C 1990 Interleukin-1 $\beta$ in human colostrum. Res Immunol 141:501-513

4. Rudloff HE, Schmalstieg FC, Palkowetz KH, Paszkiewicz EJ, Goldman AS 1993 Interleukin-6 in human milk. J Reprod Immunol 23:13--20

5. Saito S, Maruyama M, Kato Y, Moriyama I, Ichijo M 1991 Detection of Il-6 in human milk and its involvement in IgA production. J Reprod Immunol 20:267-276

6. Palkowetz KH, Royer CL, Garofalo R, Rudloff HE, Schmalstieg FC, Goldman AS 1994 Production of interleukin-6 and interleukin- 8 by human mammary gland epithelial cells. J Reprod Immunol 26:57-64

7. Subiza JL, Rodriguez C, Figueredo A, Mateos P, Alvarez R, de-la Concha EG 1988 Impaired production and lack of secretion of interleukin 1 by human breast milk macrophages. Clin Exp Immunol 71:493-496

8. Noda K, Umeda M, Ono T 1984 Transforming growth factor activity in human colostrum. Gann 75:109-112

9. Saito S, Yoshida M, Ichijo M, Ishizaka S, Tsujii T 1993 Transforming growth factor-beta (TGF- $\beta$ ) in human milk. Clin Exp Immunol 94:220-224

10. Vieira P, de Waal Malefyt R, Dang M, Johnson KE, Kastelein R, Moorc KW 1991 Isolation and expression of human cytokine synthesis inhibitory factor (CSIF/IL-10) cDNA clones: homology to Epstein-Barr virus open reading frame BCRF1. Proc Natl Acad Sci USA 88:1172-1176

11. de Waal Malefijt R, Yssel RH, Ronocarlo H, Spits H, de Vries JE 1992 Interleukin 10. Curr Opin Immunol 4:314-320

12. Howard M, O'Garra H, Ishida R, de Waal Malefyt R, de Vrics JE 1992 Biological properties of IL-10. J Clin Immunol 4:239-247

13. Fiorentino DF, Zlotnik A, Mosmann TR, Howard M, O'Garra A 1991 IL-10 inhibits cytokine production by activated macrophages. J Immunol 147:3815-3822

14. Fiorentino DF, Zlotnik A, Viera P, Mosmann TR, Howard M, Moore KW, O'Garra A 1991 IL-10 acts on the antigen-presenting cell to inhibit cytokine production by Th1 cells. J Immunol 146:3444-3451

15. de Waal Malefijt R, Abrams J, Bennett B, Figdor CG, de Vries JE 1991 Interleukin 10 (IL-10) inhibits cytokine synthesis by human monocytes: an autoregulatory role of IL-10 produced by monocytes. J Exp Med 174:1209-1220

16. Sironi M, Munoz C, Pollicino T, Siboni A, Sciacca FL, Bernasconi S, Vecchi A, Colotta F, Mantovani A 1993 Divergent effects of interleukin-10 on cytokine production by mononuclear phagocytes and endothelial cells. Eur J Immunol 23:26922695

17. Wu-J AU, Cunha FQ, Liew FY, Weiser WY 1993 IL-10 inhibits the synthesis of migration inhibitory factor and migration inhibitory factor-mediated macrophage activation. J Immunol 151:4325-4332

18. Cassatella MA, Meda L, Bonora S, Ceska M, Constantin G 1993 Interleukin 10 (IL-10) inhibits the release of proinflammatory cytokines from human polymorphonuclear leukocytes. Evidence for an autocrinc role of tumor necrosis factor and ILbeta in mediating the production of IL-8 triggered by lipopolysaccahride. J Exp Med 178:2207-2211

19. D'Andrea A, Aste-Amezaga M, Valiante NM, Ma X, Kubin M, Trinchieri G 1993 Interleukin 10 (IL-10) inhibits human lymphocyte interferon gamma-production by suppressing natural killer cell stimulatory factor/IL-12 synthesis in accessory cells. J Exp Med 178:1041-1048

20. de Waal Malefyt R, Yssel H, de Vries JE 1993 Direct effects of IL-10 on subsets of human $\mathrm{CD} 4+\mathrm{T}$ cell clones and resting T cells. Specific inhibition of IL-2 production and proliferation. J Immunol 150:4754-4765

21. Tait L, Soule HD, Russo J 1990 Ultrastructure and immunocytochemical chacterization of an immortalized human breast epithelial cell line, MCF-10. Cancer Res 50:6087-6094

22. Soule HD, Maloney TM, Wolman SR, Peterson WD, Brenz R, McGrath CM, Russo J, Pauley RJ, Brooks SC 1990 Isolation and characterization of a spontaneously immortalized human breast cpithelial cell linc, MCF-10. Cancer Res 50:6075-6086
23. Chomczinski P, Sacchi N 1987 Single-step method of RNA isolation by acid guanidinium thiocyanate-phenol-chloroform extraction. Anal Biochem 162:156-159

24. Wilcoxon F 1945 Individual comparisons by ranking methods. Biometrics 1:50-83

25. Skansén-Saphir U, Linfors A, Andersson U 1993 Cytokine production in mononuclear cells of human milk studied at the single-cell level. Pediatr Res 34:213-216

26. Neville MC, Keller R, Seacat J, Lutes V, Ncifert M, Cascy C, Allen J, Archer P 1988 Studies on human lactation: milk volumes in lactating women during the onset of lactation and full lactation. Am J Clin Nutr 48:1375-1386

27. Ho ASY, Liu Y, Khan, TA, Hsu D-H, Bazan JF, Moore KW 1993 A receptor for interleukin 10 is related to interferon reccptors. Proc Natl Acad Sci USA 90:1126711271

28. Järvenpää A-L, Rassin DK, Kuitunen P, Gaull GE, Räihä NCR 1983 Feeding the low-birth-weight infant. III. Diet influences bile acid metabolism. Pediatrics 72:677683

29. Basolo F, Conaldi PG, Fiore L, Calvo S, Toniolo A 1993 Normal breast epithelia cells produce interleukins 6 and 8 together with tumor-necrosis factor: defective IL-6 expression in mammary carcinoma. Int $J$ Cancer 55:926-960

30. Wanidworanun C, Strober W 1993 Predominant role of tumor necrosis factor-aipha in human monocyte IL-10 synthesis. J Immunol 151:6853-6861

31. Ding L, Shevach EM 1992 IL-10 inhibits mitogen-induced T cell proliferation by selcctively inhibiting macrophage costimulatory function. J Immunol 148:3133-3139

32. Hooton JWL, Pabst HF, Spady DW, Paetkau V 1991 Human colostrum contains an activity that inhibits the production of IL-2. Clin Exp Immunol 86:520-524

33. Fiorentino DF, Bond MW, Mosmann TR 1989 Two types of mouse T helper cell. IV Th2 clones secrete a factor that inhibits cytokine production by Th1 clones. J Exp Med 170:2081-2095

34. Sicling PA, Abrams JS, Yamamura M, Salgame P, Bloom BR, Rea TH, Modlin RL 1993 Immunosuppressive roles for IL-10 and IL-4 in human infection. In vitro modulation of $\mathrm{T}$ cell responses in leprosy. J Immunol 150:5501-5510

35. Powrie F, Menon S, Coffman RL 1993 Interleukin-4 and interleukin-10 synergize to inhibit cell-mediated immunity. Eur J Immunol 23:3043-3049

36. Jinquan $\mathrm{T}$, Larsen CG, Gesser B, Matsushima K, Thestrup-Pedersen K 1993 Human IL-10 is a chemoattractant for CD8 + T lymphocytes and an inhibitor of IL-8-induced CD4 + T lymphocyte migration. J Immunol 151:4545-4551

37. Fluckiger AC, Garrone P, Durand I, Galizzi JP, Banchereau J 1993 Interleukin 10 (IL-10) upregulates functional high affinity $1 \mathrm{~L}-2$ receptors on normal and lcukcmic B lymphocytes. J Exp Med 178:1473-1481

38. Briere F, Bridon JM, Servet C, Rousset F, Zurawski G, Banchereau J 1993 IL-10 and IL-13 as B cell growth and differentiation factors. Nouv Rev Fr Hematol 35:233-235

39. Armitage RJ, Macduff BM, Spriggs MK, Fanslow WC 1993 Human B cell proliferation and $\mathrm{Ig}$ secretion induced by recombinant $\mathrm{CD} 40$ ligand are modulated by soluble cytokines. J Immunol 150:3671-3680

40. Rousset F, Garcia E, Defrance T, Peronnc C, Vezzio N, Hsu DH, Kastelein R, Moore $\mathrm{KW}$, Banchereau $J 1992$ Interleukin 10 is a potent growth and differentiation factor for activated human B lymphocytes. Proc Natl Acad Sci USA 89:1890-1893

41. Defrance T, Vanbervliet B, Briere F, Durand I, Rousset F, Banchereau J 1992 Interleukin 10 and transforming growth factor beta cooperate to induce anti-CD40activated naive human B cells to secrete immunoglobulin A. J Exp Med 175:671-682

42. Linberg T, Ohlsson K, Westrom B 1982 Protease inhibitors and their relation to protease activity in human milk. Pediatr Res 16:479-483

43. Koldovsky O 1985 Digestion and absorption of carbohydrates, protein, and fat in infants and children. In: Walker WA, Watkins JB (eds) Nutrition in Pediatrics, Basic Science and Clinical Application. Little, Brown \& Co., Boston, pp 253-277

44. Kühn R, Löher J, Rennick D, Rajewsky K, Müller W 1993 Interleukin-10-deficient micc develop chronic enterocolitis. Cell 75:263-274 